\title{
LEMAK TUBUH DAN PROFIL LIPIDA DARAH ITIK BALI JANTAN YANG DIBERI RANSUM MENGANDUNG DAUN UBI JALAR UNGU (Ipomoea batatas L) DISUPLEMENTASI STARBIO DAN PIGNOX (STARPIG)
}

\author{
NI MADE SUCI SUKMAWATI, I WAYAN WIRAWAN, A.A.A. SRI TRISNADEWI, \\ DAN TJOKORDA GEDE BELAWA YADNYA \\ FAKULTAS PETERNAKAN, UNIVERSITAS UDAYANA \\ e-mail :suci_unud@yahoo.com
}

\begin{abstract}
ABSTRAK
Penelitian ini bertujuan untuk mengkaji pengaruh pemberian ransum yang mengandung tepung daun ubi jalar ungu disuplementasi Starbio dan Pignox (Starpig) terhadap lemak tubuh dan profil lipida darah itik Bali. Rancangan yang digunakan adalah Rancangan Acak Lengkap (RAL) dengan tiga perlakuan, yaitu : Ransum tanpa daun ubi jalar ungu dan Starpig (A), ransum mengandung 0,5\% daun ubi jalar ungu (B), dan ransum mengandung 0,5\% daun ubi jalar ungu disuplementasi 0,5\% Starpig (C). Setiap perlakuan terdiri dari lima ulangan, dan setiap ulangan menggunakan empat ekor itik Bali jantan umur 16 minggu. Variabel yang diamati, meliputi konsumsi antioksidan, lemak abdominal, lemak karkas, lemak tubuh, dan profil lipida darah. Hasil penelitian menunjukkan bahwa pemberian ransum mengandung daun ubi jalar ungu disuplementasi Starpig (C), nyata $(\mathrm{P}<0,05)$ dapat meningkatkan konsumsi antioksidan dan menurunkan lemak karkas, lemak abdominal, lemak tubuh, total kolesterol, HDL, LDL, dan trigliserida dibandingkan dengankontrol (A). Dari hasil penelitian ini dapat disimpulkan bahwa pemberian ransumyang mengandung tepung daun ubi jalar ungu disuplementasi Starpig dapat mengurangi lemak tubuh dan memperbaiki profil lipida darah itik Bali, umur 24 Minggu.
\end{abstract}

Kata kunci: daun ubi jalar ungu, Starpig, lemak tubuh, profil lipida darah, itik bali.

\section{THE EFFECT OF OFFERED PURPLE SWEET POTATO LEAF MEAL IN THE DIETS WITH STARBIO AND PIGNOX (STARPIG) SUPPLEMENTATION ON BODY FAT AND BLOOD LIPID PROFILE OF MALE BALI DUCKS 24 WEEKS OF AGE}

\begin{abstract}
This study was carried out to determine the effect of offered purple sweet potato leaf meal in the diets with starbio and pignox (starpig) supplementationon body fat and blood lipid profile of Bali ducks 24 weeksof age. The experimental design used was a completely randomized design thatconsisted of three treatments, and each treatment was consists of five replications with four maleBali ducks. The treatments were: A) Diets without purple sweet potato leaf meal and Starpig supplementation, B) Diets contain 0.5\% purple sweet potato leaf meal, and C) Diets contain $0.5 \%$ purple sweet potato leaf meal and 0.5\% Starpig. Variable observed were antioxidant consumption, carcass fat, abdominal fat, body fat, and blood lipid profile: cholesterol total, Trigliseride, high density lipoprotein (HDL), and low density lipoprotein (LDL). The result showed that the diets contain purple sweet potato leaf meal and Starpig supplementation, significantly $(\mathrm{P}<0.05)$ increased antioxidant consumption, and decreased body fat, carcass fat, abdominal fat,cholesterol total, LDL, HDL, and Triglyceride compared to control.It can be conclused that purple sweet potato leaf meal in the diets could decreased body fat, and improved the blood lipid profile of Bali ducks 24 weeks of age.
\end{abstract}

Keywords: purple sweet potato leaf meal, Starpig, body fat, blood lipid profile, bali ducks.

\section{PENDAHULUAN}

Itik adalah salah satu jenis ternak unggas yang memiliki potensi cukup tinggi untuk dikembangkan seba- gai sumber protein hewani (daging dan telur).Daging itik mempunyai kandungan zat gizi terutama protein yang setara dengan daging dari jenis unggas lainnya (Murtidjo, 1988). Namun demikian, daging itik mem- 
punyai kelemahan,yaitu lemak yang tinggi, daging yang alot, dan berbau amis(Setyawardani et al., 2001). Saat ini masyarakat mulai menghindari daging yang berlemak karena berkonotasi positif terhadap kandungan kolesterol yang tinggi dan mempunyai efek negatif terhadap kesehatan manusia. Oleh karena itu perlu diupayakan untuk mengurangi kandungan lemak/kolesterol dalam daging itik.Salah satu upaya yang dapat dilakukan adalah dengan membuat formulasi ransum yang mampu mengurangi pembentukan lemak/kolesterol di dalam tubuh.

Daun ubi jalar ungu adalah salah satu jenis bahan pakan alternatif penyusun ransum yang juga berfungsi sebagai obat. Sumardika dan Jawi (2010) melaporkan bahwa pemberian ekstrak daun ubi jalar ungu pada mencit hiperglikemik dapat menurunkan total kolesterol dan LDL, serta meningkatkan HDL darah pada mencit. Yang menjadi pertanyaan apakah di dalam daun ubi jalar mengandung zat antocyanin seperti yang terdapat di dalam umbi ubi jalar ungu. Ishida et al. (2000) melaporkan bahwa antocyanin pada umbi ubi jalar ungubersifat sebagai antioksidan bersifat anti radikal bebas dan dapat menekan kandungan kolesterol jahat (LDL).

Untuk meningkatkan kecernaan ransum maka perlu ditambahkan Starbio dan Pignox(Starpig). Starbio merupakanprobiotik yang berasal dari koloni mikroba alami yang berguna untuk meningkatkan nilai dan daya cerna pakan. Pemberian probiotik Starbio pada pakan ternak akan meningkatkan kecernaan ransum, kecernaan protein dan mineral fosfor (Piao et al., 1999). Pignox merupakan "feed supplement" (bahan pelengkap) buatan pabrik (Medion Bandung, 1995) yang mengandung mineral $\mathrm{Zn}$ sebanyak $20.000 \mathrm{mg} / \mathrm{kg}$ dan methionin $40.000 \mathrm{mg} / \mathrm{kg}$. Zn dan metionin sangat dibutuhkan untuk meningkatkan kerja Superoksida dismutase (SOD) sebagai zat antioksidan yang sangat dibutuhkan oleh tubuh (Ratih, 2010). Tillman et al. (1989), menyatakan mineral Zn sangat berfungsi sebagai aktivatorenzim dalam proses metabolisme.Salah satu enzim tersebut adalahkarboksi peptidase yang berperan dalam metebolisme protein. Pignox dapat membantu kerja Starbio agar proses metabolisme lebih meningkat, sehingga penampilannya menjadi lebih baik, terutama berat karkas bisa meningkat yang berarti daging yang diproduksi juga akan meningkat. Dengan adanya daun ubi jalar ungu dan Starpig diharapkan dapat meningkatkan berat karkas, menurunkan lemak abdominal,total kolesterol, LDL darah dan meningkatkan HDL darah pada itik jantan.

Penelitian ini bertujuan untuk mengkaji pengaruh pemberian ransum yang mengandung tepung daun ubi jalar ungu (Ipomoea batatas L.) yang disuplementasi Starpig terhadap lemak tubuh dan profil lipida darah itik bali jantan umur 24 minggu.

\section{MATERIDAN METODE}

\section{Tempat dan Lama Penelitian}

Penelitian dilaksanakan di Banjar Buluh, Desa Guwang, Kecamatan Sukawati, Kabupaten Gianyar, selama 8 minggu dari bulan Juli - September 2013, dan penelitian laboratorium dilaksanakan bulan September - Oktober 2013.

\section{Kandang dan Itik}

Kandang yang digunakan adalah kandang dengan sistem battery coloni yang terbuat dari bilah-bilah bambusebanyak 12 petak, masing-masingberukuran panjang $80 \mathrm{~cm}$, lebar $60 \mathrm{~cm}$ dan tinggi $70 \mathrm{~cm}$. Tiap petak kandang dilengkapi dengan tempat pakan dan minum yang terbuat dari belahan bambu. Di bawah lantai kandang diberi alas plastik untuk menampung feses.Itik yang digunakan adalah itik bali jantan umur 16 minggu sebanyak 75 ekor, yang diperoleh dari Bapak Dewa Darmada dari Desa Ketewel, Kecamatan Sukawati.

\section{Ransum dan Air Minum}

Ransum yang digunakan dihitung menurut Scott et al. (1982)dengan menggunakan bahan-bahan seperti: jagung kuning, bungkil kelapa, dedak padi, tepung ikan, kacang kedelai, daun ubi jalar ungu,dan Starpig. Air minum yang diberikan berasal dari perusahaan air minum (PAM) setempat. Komposisi bahan dan kandungan nutrisidalam ransum dapat dilihat pada Tabel 1 dan 2.

Tabel 1. Komposisi Ransum Itik Penelitian

\begin{tabular}{llccc}
\hline \multirow{2}{*}{ No $\quad$ Bahan(\%) } & \multicolumn{3}{c}{ Perlakuan $^{1}$ ) } \\
\cline { 2 - 4 } & A & B & C \\
\hline 1 Jagung kuning & 51,36 & 51,36 & 51,36 \\
2 & Bungkil kelapa & 9,31 & 9,31 & 9,31 \\
3 & Dedak padi & 18,66 & 18,66 & 18,16 \\
4 & Tepung ikan & 8,20 & 8,20 & 8,20 \\
5 & Kacang kedelai & 11,97 & 11,97 & 11,97 \\
6 & Daun ubi jalar & - & 0,50 & 0.50 \\
7 & Starpig & - & - & 0,50 \\
8 & Total & 100 & 100 & 100 \\
\hline
\end{tabular}

Tabel 2. Kandungan Zat Nutrisi dalam Ransum Penelitian

\begin{tabular}{llrrrr}
\hline \multirow{2}{*}{ No. } & Kandungan zat & \multicolumn{3}{c}{ Perlakuan $^{1)}$} & Standar \\
\cline { 3 - 5 } & nutrisi & \multicolumn{1}{c}{ A } & \multicolumn{1}{c}{ B } & \multicolumn{1}{c}{ C } & NRC(1984) \\
\hline 1 & ME(Kcal/kg) & 3007,9 & 2999,37 & 2885,49 & 2900,0 \\
2 & Protein Kasar(\%) & 17,36 & 17,70 & 16,72 & 17 \\
3 & Serat Kasar(\%) & 3,88 & 3,97 & 5,72 & $3-52)$ \\
4 & Lemak Kasar(\%) & 5,74 & 5,92 & 5,66 & $3-6$ \\
5 & Ca(\%) & 0,78 & 0,76 & 0,75 & 0,80 \\
6 & P tersedia(\%) & 0,54 & 0,56 & 0,51 & 0,50 \\
\hline
\end{tabular}

Keterangan :

1) Perlakuan:

$A=$ Ransum tanpa mengandung daun ubui jalar dan Starpig

$B=$ Ransum yang mengandung $0,5 \%$ cdaun ubi jalar ungu

$\mathrm{C}=$ Ransum yang mengandung $0,5 \%$ daun ubu jalar ungu dan $0,5 \%$ Starpig 


\section{Rancangan Percobaan}

Rancangan percobaan yang dipergunakan dalam penelitian ini adalah rancangan acak lengkap (RAL) dengan tiga perlakuan danlimaulangan.Tiap ulangan menggunakanempat ekoritik balijantan umur 16 minggu dengan berat badan homogen. Ketiga perlakuan tersebut adalah: ransum tanpa daun ubi jalar ungu dan Starpig (A), ransum mengandung daun ubi jalar ungu (B), ransum mengandung daun ubi jalar ungu dan Starpig (C).

\section{Variabel yang diamati}

Variabel yang diamati dalam penelitian ini adalah:

1. Konsumsi ransum adalah jumlah ransum yang diberikan dikurangi sisa ransum selama penelitian (kg/ekor/8 minggu)

2. Konsumsi antioksidan adalah jumlah ransum yang dikonsumsi dikalikan dengan kandungan antioksidan ransum (g/ekor/8 minggu)

3. Lemak tubuh adalah jumlah lemak yang dihasilkan pada organ dalam termasuk lemak mesentrika, lemak perut,lemak ventrikulus dan lemak karkas dibagi dengan bobot potong dikalikan 100 persen,

4. Profil lipida darah

Profil lipida darahyang diamati meliputi total kolesterol, trigliserida, HDL (High Density Lipoprotein), dan LDL (Low Density Lipoprotein). Metode yang pergunakan adalah "Enzymatic Cholesterol High Perfornce "CHOD-PAP KIT (Plummer, 1977).

\section{Analisis Statistika}

Data yang diperoleh dianalisis dengan sidik ragam, apabila terdapat hasil yang berbeda nyata $(\mathrm{P}<0,05)$ diantara perlakuan maka analisis dilanjutkan dengan uji jarak berganda dari Duncan (Steel dan Torrie, 1989).

\section{HASIL DAN PEMBAHASAN}

\section{Konsumsi Ransum}

Rataan konsumsi ransum padaitik yang tidak diberi daun ubi jalar ungu dan Starpig (perlakuan A) adalah sebesar 7,ookg/ekor/8 minggu (Tabel 3). Pemberian $0,50 \%$ tepung daun ubi jalar ungu (perlakuan B) menyebabkanpenurunan konsumsi ransum sebesar $4 \%$ $(\mathrm{P}<0,05)$ dan setelah disuplementasi dengan starbio dan pignox (perlakuan $C$ ) penurunannya bertambah menjadi 5,71\% $(\mathrm{P}<0,05)$. Penurunan konsumsi ransum tersebut ternyata tidak berpengaruh terhadap bobot potong (Tabel 3). Hal ini menunjukkan bahwa daun ubi jalar ungu dan starpig cukup efektif untuk meningkatkan efisiensi penggunaan ransum, sehingga biaya pakandapat dikurangi. Penurunan konsumsi ransum tersebut disebabkan oleh adanya antosianin pada daun ubi jalar ungu yang bersifat sebagai antioksidan dan beberapa enzim pada starbio seperti: selulase, protease, dan lipase yang mampu meningkatkan kecernaan ransum, sehingga kebutuhan energidapat terpenuhi. Ternak akan berhenti makan apabila telah merasa tercukupi kebutuhan energinya. Namun, apabila ransum tidak padat energi (tinggi serat) maka daya tampung alat pencernaan menjadi faktor pembatas utama konsumsi ransum.

\section{Konsumsi Antioksidan}

Rataan konsumsi antioksidan pada itik yang diberi ransum tanpa daun ubi jalar ungu dan Starpig (perlakuan A) adalah 30,909 g/ekor/8 minggu (Tabel 3). Pemberian $0,50 \%$ tepung daun ubi jalar ungu (perlakuan B) dan 0,50\% tepung daun ubi jalar ungu disuplementasi Starpig (perlakuan $\mathrm{C}$ ) nyata $(\mathrm{P}<0,05)$ dapat meningkatkan konsumsi antioksidan masing-masing sebesar 9,06\% dan 19,02\%. Peningkatan konsumsi antioksidan ini disebabkan oleh tingginya kandungan antioksidan dalam ransum pada perlakuan B dan C (Tabel 3). Ratih (2010) menyatakan bahwa kandungan nutrisi dalam daun ubi jalar ungu mendekati sama dengan umbi jalar ungu. Daun ubi jalar ungu juga mengandung antosianin yang bersifat sebagai antioksidan (Ishida et al., 2000). Adanya antosianin dapat meningkatkan kemampuan untuk menetralkan radikal bebas (Hillbom, 1999). Di dalam Pignox terdapat mineral Zn yang mampu meningkatkan aktivitas enzim Superoksida dismutase (SOD), sehingga pada perlakuan C kemampuan untuk menangkal radikal bebas lebih besar daripada perlakuan B atau A.

Tabel 3. Pengaruh Pemberian Ransum yang Mengandung Daun Ubi Jalar Ungu Disuplementasi Starpig terhadap Konsumsi Antioksidan Ransum dan Bobot Potong Itik Bali Jantan Umur 24 Minggu

\begin{tabular}{lccc}
\hline \multirow{2}{*}{ Variabel } & \multicolumn{3}{c}{ Perlakuan ${ }^{1)}$} \\
\cline { 2 - 4 } & $\mathrm{A}$ & $\mathrm{B}$ & $\mathrm{C}$ \\
\hline $\begin{array}{l}\text { Konsumsi ransum } \\
\text { (kg/ekor/8 minggu) }\end{array}$ & $7,00^{\mathrm{a} 2)}$ & $6,72^{\mathrm{b}}$ & $6,60^{\mathrm{b}}$ \\
$\begin{array}{l}\text { Kandungan antioksidan ransum } \\
\text { (mg/kg) }\end{array}$ & $4415,70^{\mathrm{a}}$ & $5016,17^{\mathrm{b}}$ & $6078,52^{\mathrm{c}}$ \\
$\begin{array}{l}\text { Konsumsi antioksidan } \\
\text { (mg/ekor/ 8 minggu) }\end{array}$ & $30,909^{\mathrm{a}}$ & $33,708^{\mathrm{b}}$ & $40,118^{\mathrm{c}}$ \\
$\begin{array}{l}\text { Bobot potong (g/ekor) } \\
\text { Mekor }\end{array}$ & $1385,91^{\mathrm{a}}$ & $1395,83^{\mathrm{a}}$ & $1413,85^{\mathrm{a}}$ \\
\hline
\end{tabular}

Keterangan:

1) A: Ransum tanpa ubi jalar ungu

B: Ransum mengandung $0,5 \%$ daun ubi jalar ungu ;

C: Ransum mengandung 0,5\% daun ubi jalar ungu dan 0,5\% Starpig

Superskrip yang berbeda pada baris yang sama berarti berbeda nyata $(P<0,05)$

\section{Lemak Tubuh}

Pemberian $0,5 \%$ tepung daun ubi jalar ungu secara umum dapat menurunkan kadar lemak itik bali jantan umur 24 minggu, dan lebih nyata lagi setelah disuplementasi dengan starpig. Hasil analisis ragam (Tabel 3) menunjukkan bahwa daun ubi jalar ungu (perlakuan B) 
Tabel 4. Lemak Tubuh pada Itik yang Mendapatkan Ransum Mengandung Ubi Jalar Ungu Tersuplementasi oleh Starpig

\begin{tabular}{|c|c|c|c|c|}
\hline \multirow{2}{*}{ Variabel } & \multicolumn{3}{|c|}{ Perlakuan $^{1)}$} & \multirow{2}{*}{ SEM $^{3)}$} \\
\hline & A & B & C & \\
\hline $\begin{array}{l}\text { Kadar lemak karkas } \\
\text { (\% berat potong) }\end{array}$ & $19,18^{a 2)}$ & $18,78^{a}$ & $17,59^{b}$ & 0,12 \\
\hline $\begin{array}{l}\text { Kadar lemak abdominal } \\
\text { (\% berat potong) }\end{array}$ & $1,71^{a}$ & $1,38^{b}$ & $1,33^{b}$ & 0,04 \\
\hline $\begin{array}{l}\text { Kadar lemak tubuh } \\
\text { (\% bobot potong) }\end{array}$ & $20,89^{a}$ & $20,16^{a}$ & $18,92^{b}$ & 0,37 \\
\hline \multicolumn{5}{|c|}{$\begin{array}{l}\text { Keterangan: } \\
\text { 1) Perlakuan: } \\
\text { A }=\text { Ransum tanpa mengandung daun ubui jalar dan Starpig } \\
B=\text { Ransum yang mengandung } 0,5 \% \text { daun ubi jalar ungu } \\
\text { C }=\text { Ransum yang mengandung } 0.5 \% \text { daun ubu jalar ungu dan } 0,5 \% \text { Starpig } \\
\text { 2) Superskrip yang berbeda pada baris yang sama berarti berbeda nyata }(P<0,05) \\
\text { 3) SEM: Standard Error of the Treatment Means }\end{array}$} \\
\hline
\end{tabular}

Tabel 5. Profil Lipida Darah Itik yang Mendapatkan Ransum Mengandung Tepung UbiJalar Ungu Disuplementasi Starpig

\begin{tabular}{lrrrr}
\hline \multirow{2}{*}{ Variabel } & \multicolumn{4}{c}{ Perlakuan $^{1)}$} \\
\cline { 2 - 5 } & \multicolumn{1}{c}{ A } & \multicolumn{1}{c}{ B } & \multicolumn{1}{c}{ C } & SEM $^{3)}$ \\
\hline Total kolesterol(mg/100ml) & $\left.212,46^{\mathrm{a} 2}\right)$ & $182,00^{\mathrm{b}}$ & $164,67^{\mathrm{c}}$ & 1,57 \\
Trigliserida (mg/100ml) & $222,00^{\mathrm{a}}$ & $182,67^{\mathrm{b}}$ & $173,33^{\mathrm{c}}$ & 2,32 \\
$\begin{array}{l}\text { High Density Lipoprotein } \\
\text { (mg/100ml) }\end{array}$ & $80,00^{\mathrm{a}}$ & $73,33^{\mathrm{a}}$ & $64,33^{\mathrm{b}}$ & 2,59 \\
Low Density Lipoprotein & $88,00^{\mathrm{a}}$ & $72,33^{\mathrm{b}}$ & $65,67^{\mathrm{b}}$ & 3,15 \\
(mg/100ml) & & & & \\
\hline
\end{tabular}

\section{Keterangan:}

1) Perlakuan:

$A=$ Ransum tanpa mengandung daun ubui jalar dan Starpig

$B=$ Ransum yang mengandung $0,5 \%$ daun ubi jalar ungu

$\mathrm{C}=$ Ransum yang mengandung $0,5 \%$ daun ubu jalar ungu dan $0,5 \%$ Starpig

2) Superskrip yang berbeda pada kolom yang sama berarti berbeda nyata $(P<0,05)$

3) SEM: Standard Error of the Treatment Mean

nyata $(\mathrm{P}<0,05)$ dapat menurunkan lemak abdominal sebesar 19,30\%, sementara lemak karkas dan lemak tubuh berbeda tidak nyata $(\mathrm{P}>0,05)$ dibandingkan dengan kontrol (perlakuan A). Ransum yang mengandung daun ubi jalar ungu disuplementasi Starpig (perlakuan C) secara nyata $(\mathrm{P}<0,05)$ dapat menurunkan lemak karkas sebesar 8,29\%, lemak abdominal 22,22\%, dan lemak tubuh sebesar 9,43\% dibandingkan dengan pemberian ransum kontrol. Hal ini disebabkan oleh adanya mineral $\mathrm{Zn}, \mathrm{Cu}$ dan $\mathrm{Mg}$ dalam Pignox yang dapat meningkatkan kapasitas antioksidan (Kumalaningsih, 2008), terutama Superoksida dismutase (SOD). Selain mengikat radikal bebas, antioksidanjuga berfungsi mengikat lemak dan dibawa ke bagian belakang pada senyawa siklis melalui ikatan kovalen.Sebagian lemak dikeluarkan melalui feses,dan sebagianlagi diserap oleh tubuh menjadi lemak abdominal.Hal tersebut menyebabkan lemak karkas menjadi berkurang dan akanmenurunkan kadar lemak tubuh secara nyata.

\section{Profil Lipida Darah}

Profil lipida darah (total kolesterol, trigliserida, HDL dan LDL) pada itik yang mendapat perlakuan A (ransum tanpa daun ubi jalar ungu dan starpig) masingmasing sebesar 212,46 mg/100ml, $222 \mathrm{mg} / 100 \mathrm{ml}, 80$ mg/10oml dan 88 mg/10oml (Tabel 5). Pemberian 0,50\% tepung daun ubi jalar ungu (perlakuan B) secara nyata $(\mathrm{P}<0,05 \%)$ dapat menurunkan kadar kolesterol darah sebesar $14,34 \%$, trigliserida $17,72 \%$, LDL 17,81\%, sementara HDL berbeda tidak nyata $(\mathrm{P}>0,05 \%)$. Daun ubi jalar ungu yang disuplementasi dengan starpig (perlakuan $\mathrm{C}$ ) secara nyata $(\mathrm{P}<0,05)$ dapat menurunkan kadar kolesterol darah sebesar 22,49\%; trigliserida 21,92\%; HDL 19,59\%; dan LDL 25,38\% dibandingkan dengan kontrol (A).

Penurunan kadar kolesterol darah sangat terkait dengan adanya antosianin yang terdapat pada daun ubi jalar ungu serta adanya mineral $\mathrm{Zn}, \mathrm{Cu}$ dan $\mathrm{Mg}$ didalam Pignox sebagai sumber antioksidan.Antioksidan dapat menghambat aktivitas enzim HMG-KoA reduktase yang merubah 3-Hidroksi, 3-Methyl, Gluteryl-Ko.A menjadi asam mevalonat. Asam mevalonat adalah senyawa awal dalam proses pembentukan kolesterol. Dengan berkurangnya asam mevalonat, maka kolesterol yang dihasilkan di hati akan berkurang (Agarwal dan Rao, 2000), demikian pula kolesterol dalam sirkulasi darah. Dengan demikian, kadar HDL, LDL dan trigliserida juga berkurang. Hasil penelitian ini didukung oleh Sumardika dan Jawi (2010) yang melaporkan bahwa pemberian ekstrak daun ubi jalar ungu dapat menurunkan total kolesterol dan LDL darah tikus. Selanjutnya, Yadnya (2012) melaporkan bahwa pemberian tepung ubi jalar ungu pada taraf $30 \%$ dalam ransum dapat memperbaiki profil lipida darah dan daging itik yang berumur 3 sampai 15 minggu.

Dari hasil penelitian ini dapat disimpulkan bahwa pemberian ransum yang mengandung tepung daun ubi jalar ungu disuplementasi starpig dapat mengurangi lemak tubuh dan memperbaiki profil lipida darah itik bali jantan umur 24 minggu.

\section{UCAPAN TERIMA KASIH}

Ucapan terima kasih penulis persembahkan kepada Rektor Universitas Udayana, melalui Ketua Lembaga Penelitian dan Pengabdian Kepada MasyarakatUniversitas Udayana, atas dana yang diberikan dalam DIPA (Dosen Muda) Tahun Anggaran 2013, sehingga penelitiann dapat berjalan dengan semestinya.

\section{DAFTAR PUSTAKA}

Agarwal, S., and Rao, A.V, 200o. Role ofAntioxidant Lycopene in Cancer and Heart Disease. J.Coll.Nutr. (19 (5): 563-9

Hillbom. 1999. Oxidant, Antioxidant, and Stroke. Fronties in Bioscience, 4e August 15, 1999: 67- 71

Ishida, H., Suzuno, H., Sugiyana ,N., Innami, S., Tadokoro, T., Maekawa A. 2000. Nutritive Evaluation on Chemical Component of Leaves, Stalks and Stems of Sweet Potatoes (Ipomoea batatas poir). I. Food Chemistry, 
68: $359-367$

Kumalaningsih, S. 2008. Antioksidan Superoksida dismutase (SOD), Antioxidant, Centre. Com. http: // antioxidant centre.com (10 Januari 2008).

Murtidjo, B. A. 1988. Mengelola Itik. Penerbit Kanisius, Yogyakarta.

National Research Council (NRC). 1984. Nutrient Requirements of Poultry. Right Revised Edition, 1984. National Academiy Press, Washington,D.C.1984.

Piao, X. S., Han, I. K., Kim, J. H., Cho, W. T., Kim, Y. H., and Liang, C. 1999. Effects of Kemzyme, Phytase, and Yeast Supplementation on the Growth Performance and Pollution Reduction of Broiler Chicks. Asian-Aust. J.Anim. Sci. $12(1): 36-41$

Plummer, D.T. 1977. An Introduction to Practical Biochemestry. Mc.Grand Hill, Book Co.Ltd, New Delhi.

Ratih. 2010. Manfaat dibalik Ubi Jalar Ungu. Blog Konsultasi Gizi. Com/info/manfaat-di-balik-ubi-jalar-ungu.ht

Scott, M. L, Neiheim, M, C. and Young ,R.J.. 1982. Nutition of the Chickens M. K. Scott and Associates, New York.

Setyawardani, T., Ningsih, D., Fernando D., dan Arcarwah. 2001. Pengaruh Pemberian ekstrak buah nenas, dan pepaya terhadap kualitas daging itik petelur afkir. $\mathrm{Bu}$ letin Peternakan. Diterbitkan oleh Fakultas Peternakan Universitas Gadjah Mada,Yogyakarta. ISSN.0126-4400, Edisi Tambahan, Desember 2001.

Steel, R. G. D. and Torrie J. H.. 1989. Principle and Procedures of Statistcs, $2^{\text {nd }} \mathrm{Ed}$. McGraw-Hill International Book Co. London.

Sumardika, I W. dan Jawi I M. 2010. Pengaruh pemberian ekstrak daun ubi jalar ungu (Ipomoea batatas)terhadap profil lipida dan superoxide dismutase pada serum darah mencit. Laporan Penelitian Laboratorium Parmakology,Fakultas Kedokteran. Univ. Udayana.

Tillman, A. D., H. Hartadi, S. Reksodoprojo, S. Prawiro Kusumo, S. Lebdosoekojo. 1998. Ilmu Makanan Ternak Dasar. Gadjah Mada University Press, Yogyakarta.

Yadnya, TGB. 2012. The Used of Purple Sweet Potato (Ipomoea batatas L) ration fermented by Aspergillus niger for to Improved of Feed Convertion and Profile Lipid of Bali Duck Blood. ${ }^{\text {th }}$ International Coference on Biosciences and Biotechnology. ICBB - Bali, Bali September $20-21,2012$ 